\title{
SCREENING OF THERMOSTABLE PROTEASE PRODUCING MICROORGANISMS ISOLATED FROM INDONESIAN HOTSPRING
}

\section{Penapisan Mikroorganisme Penghasil Protease Tahan Panas yang Diiisolasi dari Sumber Air Panas Indonesia}

\author{
Dewi Seswita Zilda ${ }^{1)^{*}}$, Eni Harmayani ${ }^{2)}$, Jaka Widada ${ }^{2)}$, Widya Asmara' ${ }^{2)}$, Hari Eko Irianto'), \\ Gintung Patantis ${ }^{1)}$ and Yusro Nuri Fawzya ${ }^{1)}$ \\ ${ }^{1)}$ Research and Development Center for Marine and Fishery Product Processing and Biotechnology \\ 2)Biotechnology Study Program, Gadjah Mada University \\ "Corresponding author: seswitazilda@yahoo.com
}

\begin{abstract}
Although many proteases had been studied and characterized, only a few of them are commercially available. Protease thermostability is one of the crucial properties for industrial application. This research aimed to isolate and to screen the potential isolate which produce thermostable protease. There were 6 isolates (BII-1, BII-2, BII-3, BII-4, BII-6 and LII), isolated using solid Minimal Synthetic Medium (MSM) supplemented with $1.5 \%$ skim milk, that have, protease activity. Based on the 16S-rRNA gene sequencing analysis, isolates BII-1, BII-2 and BII6 were identified as Bacillus licheniformis, isolates BII-3 and Bll-4 were identified as Bacillus subtilis, while isolate LII was identified as Brevibacillus thermoruber. Three isolates (BII-6, BII-4 and LII) were then further investigated for the second screening step using liquid MSM supplemented with $1 \%$ skim milk. The isolates (BII-6, BII-4 and LII) optimally produced protease when they were cultivated at 35,30 and $50{ }^{\circ} \mathrm{C}$ respectively after $22 \mathrm{~h}$ of incubation. Protease produced by BII-6, BII-4 and LII had optimum temperature of 65,60 and $85{ }^{\circ} \mathrm{C}$, optimum pH at 78,8 and 9 and stable up to $100 \mathrm{~min}$ at 55,60 and $75^{\circ} \mathrm{C}$ respectively.
\end{abstract}

\section{Keywords: thermostable protease, Bacillus subtillis, Bacillus licheniformis, Brevibacillus thermoruber}

\begin{abstract}
ABSTRAK
Meskipun banyak protease yang sudah dipelajari dan dikarakterisasi, hanya beberapa yang tersedia secara komersial. Ketahanan protease terhadap panas merupakan salah satu sifat penting untuk diaplikasikan di industri. Penelitian ini bertujuan untuk mengisolasi dan menapis isolat potensial yang menghasilkan protease yang tahan terhadap panas. Ada 6 isolat bakteri (BII-1, BII-2, BII-3, BII-4, BII-6 dan LII) yang diisolasi dengan menggunakan media padat Minimal Synthetic Medium (MSM) dengan penambahan 1,5\% skim milk mampu menghasilkan protease. Analisis susunan gen 16S rRNA terhadap keenam isolat menunjukkan bahwa hanya ada 3 isolat berbeda yang teridentifikasi sebagai Bacillus licheniformis (BII-1, Bll-2 dan Bll-6), Bacillus subtilis (BII-3 dan BII-4) dan Brevibacillus thermoruber(LII). Tiga isolat (BII-6, BII-4, dan LII) selanjutnya diteliti lebih lanjut untuk penapisan kedua menggunakan medium cair MSM dengan penambahan $1 \%$ skim milk. Isolat-isolat ini menghasilkan protease secara optimal ketika dikultivasi pada suhu 35,30 , dan $50{ }^{\circ} \mathrm{C}$ untuk masing-masing isolat setelah inkubasi selama 22 jam. Protease yang dihasilkan oleh BII-6, BII-4 dan LII berturut-turut mempunyai suhu optimum 65,60 dan $85^{\circ} \mathrm{C}$, pH optimum 7-8, 8-9 dan stabil sampai 100 menit pada suhu 55 , 60, dan $75^{\circ} \mathrm{C}$ untuk masing-masing isolat.
\end{abstract}

Kata kunci: protease tahan panas, Bacillus subtillis, Bacillus licheniformis Brevibacillus thermoruber

\section{INTRODUCTION}

Proteases (EC 3.4.21-24 and 99; peptidyl-peptide hydrolases) are enzyme that hydrolyze proteins via the addition of water across peptide bonds and catalyze peptide synthesis in organic solvents and in solvents with low water content (Beg et al., 2003). Proteases, which constitute $60 \%$ of the total enzyme market (Rao et al., 1998) is the most vital enzyme used industrially and academically. The use of 
protease was estimated reaching to 250 billion US\$ by 2010 (Turk, 2006; Mario et al., 2009; Akanbi et al., 2010). They are widely applied in detergent, protein modification, leather, meat, brewing, photographic, dairy, membrane cleansing and waste treatment industries (Kumar et al., 2002; Chu, 2007). The demand of the enzyme will keep increasing due to the need of the enzyme which can withstand on harsh industrial process.

Thermostability is the crucial properties of enzyme for industrial application. Thermostable proteases are stable and active above $60-70{ }^{\circ} \mathrm{C}$ and withstand to organic solvent, detergent, low and high $\mathrm{pH}$ and other denaturing agents (Covan et al., 1985; Covan, 1997; Gupta \& Khare, 2006) so that it is particular interest in industrial process. Thermostable proteases has high specific activity due to the protein characteristic as substrate for proteases which unfolded at elevated temperature. They also useful in synthesis of high molecular weight peptide due to their resistance against organic solvents carried out in process with low water content (Sellek \& Chaudhuri, 1998; Bruins et al., 2001; Synowiecki, 2008).

Commercially, protease are produced by plants, animals and microorganisms. Microorganisms are attractive sources for protease and other enzymes due to their ability to be cultured in large scale in short fermentation time with abundant desire product. To improve the enzyme performance, their genes can be manipulated easier than plants and animals (Tambekar et al., 2009; Ningthoujam \& Kshetri, 2010).

Enzymologists have special interest to thermophilic microorganisms both at the fundamental and industrial level as natural source of enzymes that are active and stable at elevated temperatures. Hot spring as one of thermophile habitats is considered as promising source for the direct isolation of thermostable enzymes. The microorganisms living in hot spring are not only withstand to elevated temperature but also to the $\mathrm{pH}$ of environment and the presence of certain chemical compounds. Some of thermostable protease producing microorganisms were isolated from hot spring as reported by Pakpahan (2009) who isolated three unidentified isolates from Sipolohon hotspring, North Tapanuli, North Sumatera. Wilson \& Remigio (2012) also reported novel moderate thermophilic bacterium (EP1001) as thermostable protease producer isolated from an alkaline hot spring, Zimbabwe.

The objective of the research was to isolate and to screen the potential isolate which produce thermostable protease from Indonesian hotspring, i.e Padang Cermin (Lampung) and Banyu Wedang(Bali). In this study, screening were conducted in two steps. The first step was carried out using solid media and the second step was done using liquid media, followed by proteases characterization. The potential isolates were choosen based on its ability to produce protease which active and stable at highest temperature.

\section{MATERIAL AND METHOD}

\section{Screening of Protease Producing Micro- organisms Using Solid Medium}

Thermostable producing bacteria was isolated from samples collected from hot springs at Padang Cermin, Lampung and Banyu Wedang, Bali using solid medium of Minimal Synthetic Medium (MSM) containing of $0.1 \% \mathrm{NaCl}, 0.1 \% \mathrm{~K}_{2} \mathrm{HPO}_{4}, 0.01 \%$ $\mathrm{MgSO}_{4}, 7 \mathrm{H}_{2} \mathrm{O}, 0.05 \%$ yeast extract and supplemented with $1 \%$ skim milk. The incubation was carried out at 37,55 and $70^{\circ} \mathrm{C}$. The clear zone formed around the colony indicated the ability of the isolate to produce protease and designated as the Proteolytics Index (PI). The Proteolitics Index was determined by measuring diameter of clear zone around the colony compare to diameter of the colony. The purified cultures were preserved in $40 \%$ glycerol and stored at $-70^{\circ} \mathrm{C}$.

\section{Phylogenetic Analysis by 16 S rRNA Gene Sequencing}

Bacteria's DNA was extracted using TIANamp Bacteria DNA Kit. A 16S-rRNA (1.47 kbp) fragment was amplified by PCR using a pair of universal primers (16S rDNA"27F and 16S rDNA"1492R). Fifty $\mu$ l of the reaction mixture contained $1 \mu$ chromosomal DNA, 2 $\mu \mathrm{l}$ primer, $22 \mu \mathrm{l}$ ultrapure water and $25 \mu \mathrm{l}$ 2xTag PCR Master Mix (Tlangen Biotech, China). The PCR reaction was set as: denaturation at $95^{\circ} \mathrm{C}$ for $5 \mathrm{~min}$ and 30 cycles of annealing at $55^{\circ} \mathrm{C}$ for $30 \mathrm{~s}$, extension at $72{ }^{\circ} \mathrm{C}$ for $90 \mathrm{~s}$ and denaturation at $95^{\circ} \mathrm{C}$ for $60 \mathrm{~s}$. Final extention was carried out after 30 cycle at $72^{\circ} \mathrm{C}$ for $10 \mathrm{~min}$. The nucleotide sequences of the fragment were identified using 3730 DNA sequencer (Applied Biosystems, CA, USA) and subjected to a homology search against NCBI DNA database using BLAST (Basic Local Alignment Search Toil) (Altscul et al., 1990) then aligned using Clustal W program (Higgins et al., 1992) available at European Bioinformatics Institute website (http://www.ebi.ac.uk/clustalw/). The sequence retrieve from Gene Bank data base (Benson et al., 2003) available at the NCBI website (http:// www.ncbi.nlm.nih.gov/). Clustal analysis (Sokal \& Sneath, 1963) and the neighbor-joining mid point analysis (Saitou \& Nei, 1987; Rohlf, 1993) were performed using TREECON for Windows (Version 1.3b) (Van der Peer \& De Wachter, 1994). The consistency of each node was estimated by 
bootstrapping over markers (Felsenstein, 1985) using 100 pseudoreplications.

\section{Srceening in Liquid Medium}

Three different species (based on 16S-rRNA analysis) of protease producing bacteria isolated from previous screening step were cultured in liquid MSM medium with $1 \%$ skim milk and incubated for $35 \mathrm{~h}$ at $25-60{ }^{\circ} \mathrm{C}$. The free cell supernatant was measured for protease activity at optimum condition for each isolate.

\section{Protease Assay}

Protease activity was determined by applying a modified method by Takami et al. (1989). The mixture containing of $0.25 \mathrm{ml}$ of $1 \%$ casein in 0.025 Tris-Cl buffer $\mathrm{pH} 7$ was incubated with $0.25 \mathrm{ml}$ of enzyme for $10 \mathrm{~min}$. The reaction was stopped by adding 0.5 $\mathrm{mL}$ of $0.4 \mathrm{M}$ TCA. The mixture was centrifuged at $10.000 \mathrm{rpm}$ for $10 \mathrm{~min}$. Supernatant $(0.5 \mathrm{ml})$ was mixed with $2.5 \mathrm{ml}$ of $0.4 \mathrm{M} \mathrm{Na}_{2} \mathrm{CO}_{3}$ and $0.25 \mathrm{ml}$ of FolinCiocalteu's Phenol Solution and incubated for $30 \mathrm{~min}$ at room temperature. The absorbance of the solutions were read against the blank sample at $660 \mathrm{~nm}$ using Spectronic ${ }^{\circledR} 20$ Genesys $^{\mathrm{TM}}$. Tyrosin standard solution, in the range of $0-1000 \mathrm{mg} / \mathrm{L}$ was prepared in triplicate to obtain a standard curve. One unit $(U)$ of protease was defined as the amount of enzyme that could produce $1 \mu \mathrm{g}$ of tyrosine in one minute under the defined assay conditions.

\section{Partial Characterization}

Optimum Temperature and $p H$. Optimum temperature was determined by measuring enzyme activity at $40-90^{\circ} \mathrm{C}$. Optimum $\mathrm{pH}$ for enzyme assay was determined by measuring the enzyme activity using substrate with $\mathrm{pH}$ of $4-10$ at optimum temperature.

Thermal Stability. The stability of enzyme against thermal was determined by incubating the enzyme in $20 \mathrm{mM}$ buffer Tris- $\mathrm{HCl}$ at optimum $\mathrm{pH}$ for each isolate at three temperature levels $\left(65,60\right.$ and $55^{\circ} \mathrm{C}$ for BII- 6 , 60,55 and $50^{\circ} \mathrm{C}$ for BII-4, 85, 80 and $75^{\circ} \mathrm{C}$ for LII) up to $100 \mathrm{~min}$. The enzyme activity was measured every 10 min and expressed as relative activity against the enzyme without thermal treatment as $100 \%$ enzyme activity.

\section{RESULT AND DISCUSSION}

\section{Screening on Solid Medium}

The sampling site were located at Padang Cermin, Lampung (5 ${ }^{\circ} 37^{\prime} 59^{\prime \prime}$ LS; 105 $04^{\prime} 20^{\prime \prime}$ BT) and Banyu Wedang, Bali ( $8^{\circ} 10^{\prime} 38^{\prime \prime}$ LS; $\left.114^{\circ} 35^{\prime} 26^{\prime \prime}\right)$. The properties of samples were presented at Table 1.

The screening and isolation of protease producing bacteria were carried out at $55^{\circ} \mathrm{C}$ to obtain the thermostable protease producing isolates. There were 6 isolates grown on MSM plate agar containing of $1.5 \%$ skim milk and formed clear zone around of the colony after 30 hours incubation at $55^{\circ} \mathrm{C}$ (Fig 4.). The code and Proteolitics Index of the isolates were presented at Table 2. Isolates from Banyu Wedang had bigger PI value of $12.5-15.5 \mathrm{~mm}$ compared to that from Padang Cermin, which was $4 \mathrm{~mm}$. However, the value of $\mathrm{PI}$ was not the only indicator for obtaining a

Table 1. Temperature and $\mathrm{pH}$ of in situ Sample

\begin{tabular}{ccccl}
\hline Code of Isolates & Salinity $\left(\% \%_{\mathrm{oo}}\right)$ & $\mathbf{p H}$ & Temperature $\left({ }^{\circ} \mathrm{C}\right)$ & Source of Isolates \\
\hline LII & $4-5$ & 6,9 & 97 & $\begin{array}{l}\text { Padang Cermin, } \\
\text { Lampung }\end{array}$ \\
BII & 4 & 8,1 & 44,8 & Banyu wedang, Bali \\
\hline
\end{tabular}

Table 2. Proteolitics Index of Protease Producing Microorganisms 


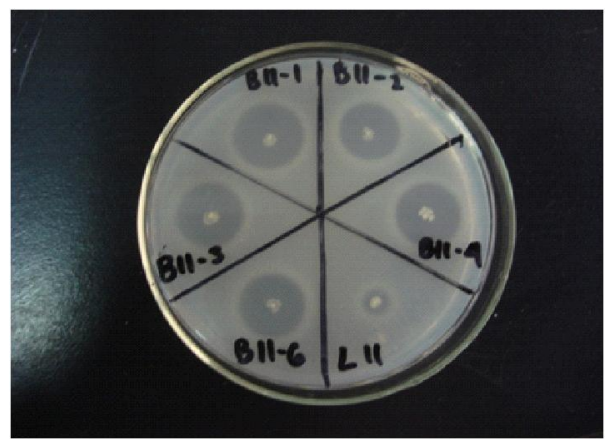

Figure 1. Protease producing microorganisms on agar plate with $1 \%$ skim milk.

potential protease. The indicator of thermostable protease producing bacteria is the ability of the isolate to produce protease which has optimum temperature and stable at the highest temperature.

Therefore, a second step of screening was conducted by growing the potential isolates in liquid medium and measuring the activity at a series of temperature and $\mathrm{pH}$, and investigated their stability against thermal.

\section{Phylogenetic Analysis by 16S rRNA Gene Sequencing}

The analysis of 16S-rRNA sequensing showed that BII-1,BII-2 and BII-6 gave 99\% similarity to Bacillus licheniformis, while BII-3 and BII-4 had 99\% similarity to Bacillus subtilis and LII had $99 \%$ similarity to Brevibacillus thermoruber.
Most of thermostable proteases were reported to be produced by Bacillus sp. such as Bacillus stearothermophilus (Salleh et al., 1977; Razak et al., 1993) Bacillus caldolyticus (Burg et al, 1991), Bacillus subtilis (Ningthoujam \& Kshetri, 2010), Bacillus cereus (Jabeen \& Qazi, 2011) and Bacillus mojavensis (Haddar, 2009). On the other hand, only few other types of bacteria that were reported to produce thermostable protease such as Aquifex pyrophilus (Choi et al., 1999) and Pseudomonas sp. (Asoodeh \& Musaabadi, 2012).

\section{Screening on Liquid Medium}

The first step of screening was carried out at $55^{\circ} \mathrm{C}$ on solid medium supplemented with $1.5 \%$ skim milk resulted 6 isolates forming clear zone around the colony indicating that the isolates had protease activity (Fig 1.). The second screening step was conducted by testing the most potential isolate for

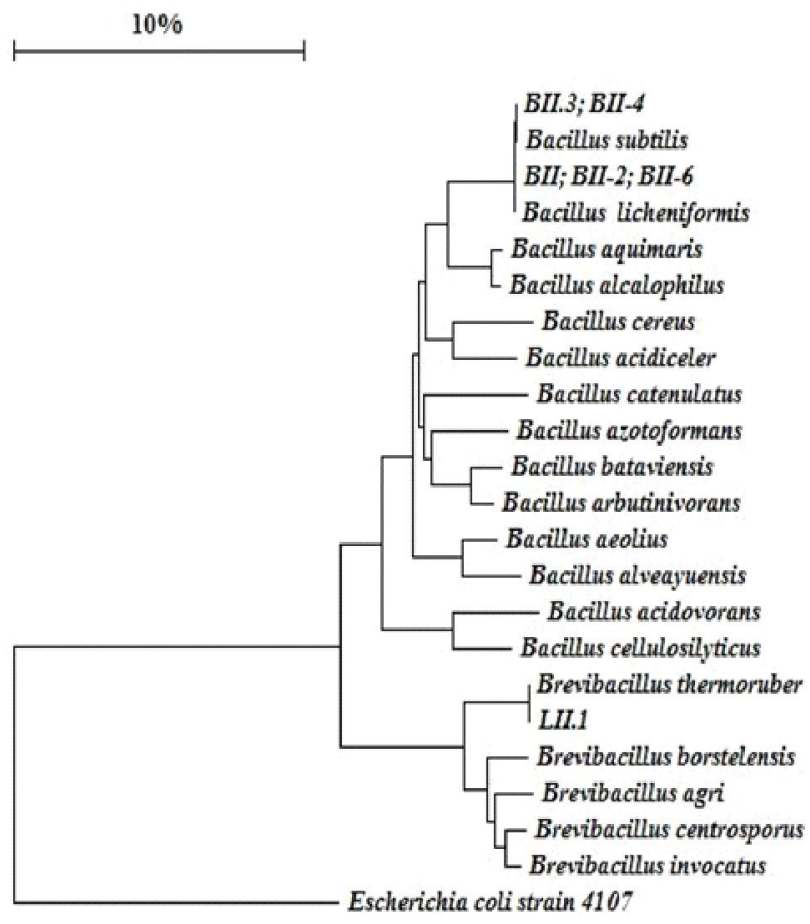

Figure 2. Phylogenetic tree of protease producing microrganisms. 
their ability to produce protease in liquid medium which active and stable at highest temperature. Isolate BII6 and BII-4 were not able to grow at $55^{\circ} \mathrm{C}$ and the 16S-rRNA identification showed that the isolates had 99\% similarity to Bacillus licheniformis and Bacillus subtilis respectively. Hadaar (2009) and Ningthoujam \& Kshetri (2010) reported two protease producing isolates that were classified as mesophile and grow optimally at $30-35^{\circ} \mathrm{C}$. Therefore, the three different species isolates (BII-6, BII-4 and LII ) were grown in liquid MSM supplemented with $1 \%$ skim milk and incubated up to $34 \mathrm{~h}$ at $25-40{ }^{\circ} \mathrm{C}$ for BII-6 and BII-4 isolates, and $45-55^{\circ} \mathrm{C}$ for LII isolate.
The result showed that the highest protease activity was produced at temperature 35,30 and $50{ }^{\circ} \mathrm{C}$ for BII-6, BII-4 and LII respectively (Fig 3.). The protease was produced by isolates after $22 \mathrm{~h}$ incubation. The optimum temperature of the proteases were 65,60 and $85^{\circ} \mathrm{C}$ (Fig 4.), and optimum $\mathrm{pH}$ were $7-8,8$, and 9 for BII-6, BII-4 and LII respectively (Fig 5.). The protease produced by LII showed the stability up to $100 \mathrm{~min}$ against thermal at highest temperature $\left(75^{\circ} \mathrm{C}\right)$ while protease from BII-2 and BII-6 at 55 and $50{ }^{\circ} \mathrm{C}$ respectively (Fig. 6). All isolates produced protease with optimum temperature above the optimum temperature for their growth and enzyme production.
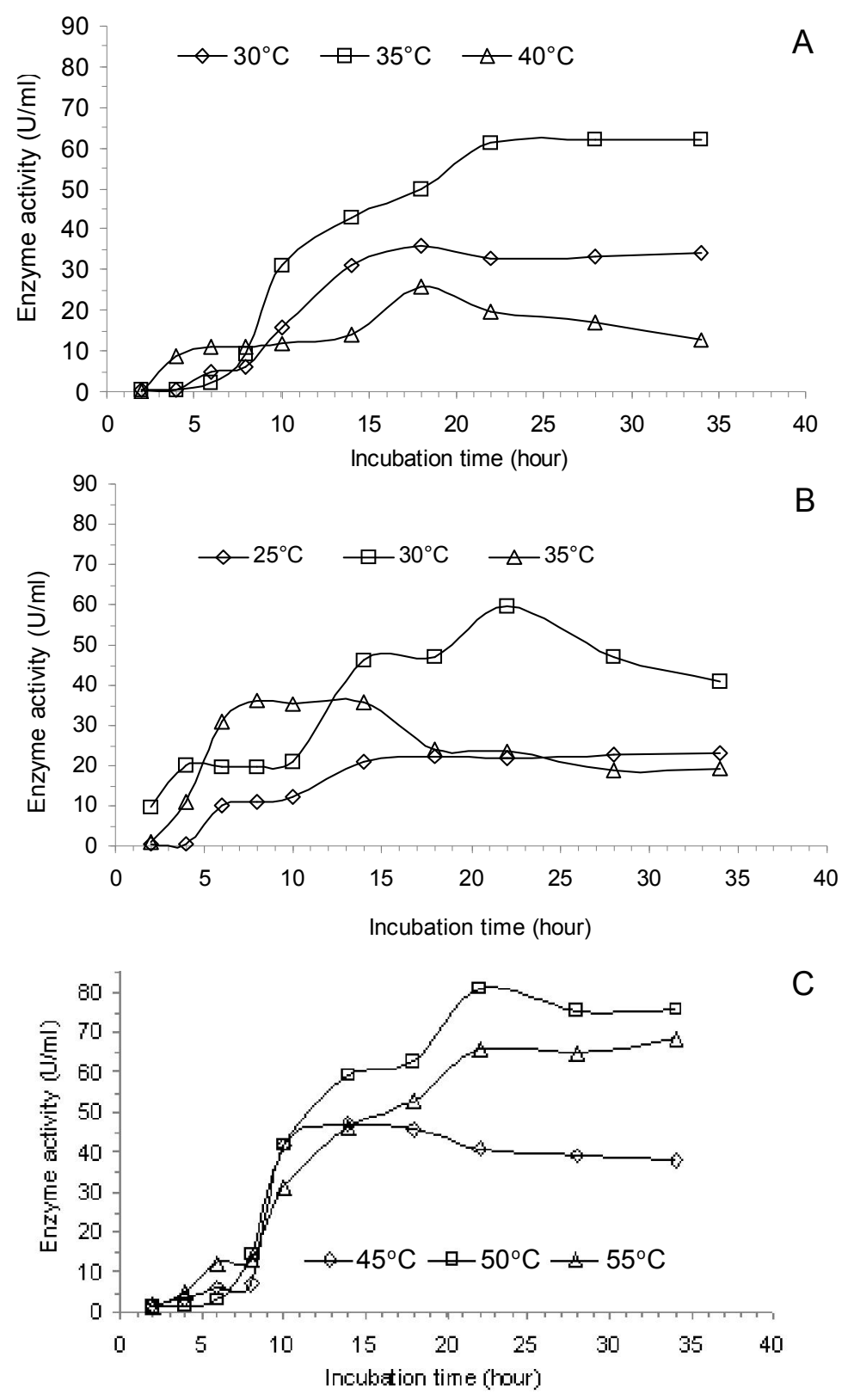

Figure 3. Effect of incubation temperatures on protease production (A): BII-6; (B): BII-4; (C): LII. 

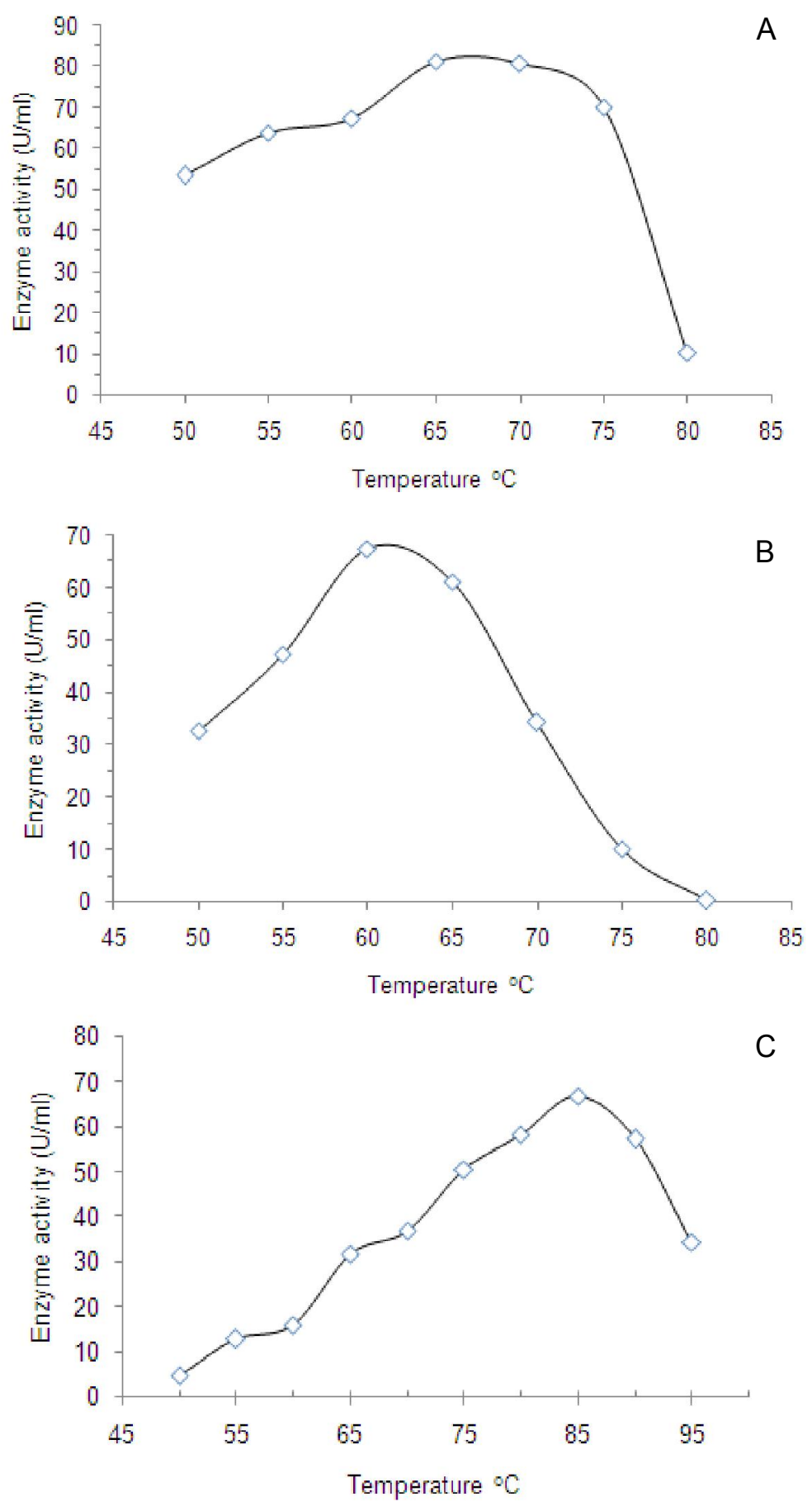

Figure 4. Effect of temperature on enzyme activity (A): BII-6; (B): BII-4; (C): LII.

These were in accordance with the previous result as shown by the thermophilic bacterium EP1001 which produced protease at $45^{\circ} \mathrm{C}$ with optimum temperature for the enzyme activity of $75^{\circ} \mathrm{C}$ (Wilson \& Remigio, 2012), and Bacillus subtilis SH1 produced protease at $30^{\circ} \mathrm{C}$ with optimum temperature for the enzyme activity of $50^{\circ} \mathrm{C}$ (Ningthoujam \& Kshetri, 2010). Other researches also reported the similar result (Salleh et al., 1977; Burg et al, 1991; Razak et al., 1993; Choi et al., 1999; Haddar, 2009; Jabeen \& Qazi, 2011; Asoodeh \& Musaabadi, 2012).

This study also showed that both Bacillus licheniformis BII-6 and Bacillus subtilis BII-4 isolated from Banyu Wedang hot spring at temperature of $44.8^{\circ} \mathrm{C}$, were mesophile bacteria. The two isolates produced thermostable protease when cultivated at 

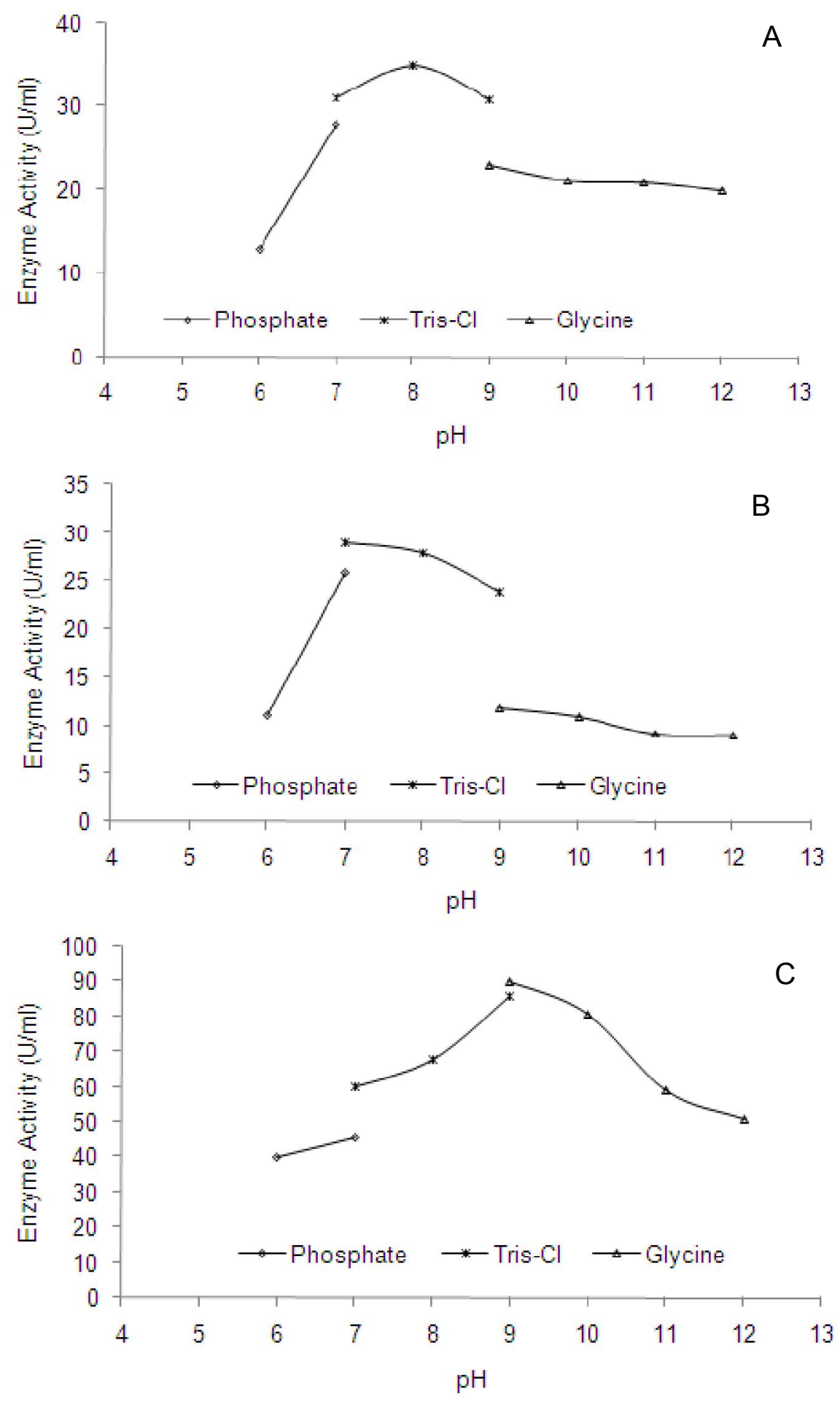

Figure 5. Effect of pH on enzyme activity (A): BII-6; (B): BII-4; (C): LII.

35 and $30^{\circ} \mathrm{C}$, eventhough both isolates could survive at temperature up to $55^{\circ} \mathrm{C}$ and produce clear zones around the colony on agar plate containing skim milk.

The investigation showed that the clear zone around the colony or Proteolitics Indeks (PI) on agar plate can only be used to screen protease producing bacteria but not to compare the ability of isolates to produce the potential protease as reported by Srinivasan et al. (2009); Ningthoujam \& Kshetri (2010); and Bayoumi \& Bahobil (2011). The characteristics of potential thermostable protease, signed by its ability to withstand against thermal, was showed by further 

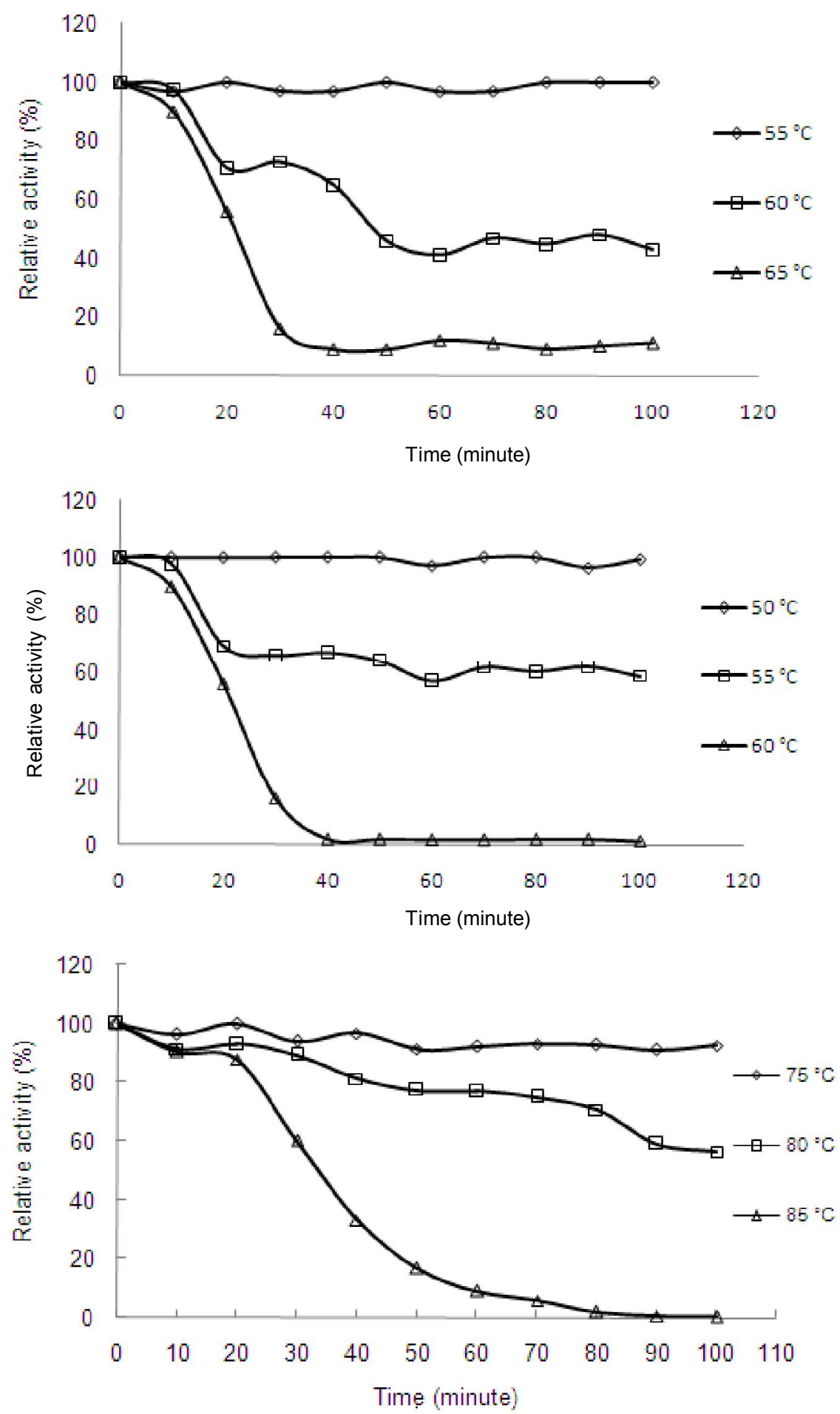

Figure 6. Effect of temperatures on enzyme stability (A): BII-6; (B): BII-4; (C): LII.

investigation, i.e by growing the isolates in liquid medium. Isolate LII, which only showed barely clear zone on agar plate (Fig. 1 and Table 2), produced thermostable protease with higher activity compare to others (Fig. 3). Protease produced by LII also showed the highest optimum temperature as well as the stability against thermal (Fig. 5 and Fig. 6).

\section{CONCLUSION}

There were 6 protease producer isolates (BII-1, BII2, BII-3, BII-4, BII-6 and LII) obtained from screening using solid MSM supplemented with $1.5 \%$ skim milk. Based on 16S-rRNA analysis those isolates were identified as Bacillus licheniformis (BII-1, BII-2 and 
BII-6), Bacillus subtilis (BII-3 and BII-4) and Brevibacillus thermoruber (LII).

Further screening on three different isolates (BII6, BII-4 and LII) in liquid medium revealed that the LII isolate as the most potential protease producer. The enzyme had characteristics of optimum temperature of $85^{\circ} \mathrm{C}$, optimum $\mathrm{pH}$ of 9 and stable for up to $100 \mathrm{~min}$ at $75^{\circ} \mathrm{C}$.

\section{REFERENCES}

Akanbi, T.O., Kamaruzaman, A.L., Abu, B.F., Sheikh, A.H. N., Radu, S., Abdul, M.Y., Manap, and Saari, N. 2010. Highly thermostable extracellular lipase-producing Bacillus strain isolated from a Malaysian hotspring and identified using 16S rRNA gene sequencing. Inter. Food Res. J. 17: 45-53.

Altscul, S.F., Gish, W., Miller, W., Myers, E.W., and Lipman, D.J. 1990. Basic local alignment search tool. J. Mol. Biol. 215: 403-410.

Asoodeh, A. and Mussaabadi, H.M. 2012. Purification and characterization of a thermostable neuthrophilic metalloprotease from Pseudomonas sp. DR89. Iranian J. of Biotech. 10: 120-128.

Bayoumi, R.H. and Bahobil, A.S. 2011. Production of thermoalkaliphilic protease by Shewanella putrefaciens-EGKSA21 under optimal conditions for application in biodetergent technology. J. Basic. Appl. Sci. Res. 1: 95-107.

Beg, Q.K., Sahai, V., and Gupta, R. 2003. Statistical media optimization and alkaline protease production from Bacillus mojavensis in a bioreactor. Proc. Biochem. 39: 203-210.

Benson, D.A., Karsch-Mizrachi, I., Lipman, D.J., Ostell, J., Rapp, B.A., and Wheeler., D.L. 2003. GenBank. Nucleic Acids Res. 31: 23-27.

Bruins, M.E., Janssen, A.E.M., and Boom, R.M. 2001. Thermozymes and their applications. Appl. Biochem. Biotechnol. 90: 155-186.

Burg, B.V.D., Enequist, H.G., Haar, M.E.V.D., Eijsink, V.G.H., Stulp, B.K., and Venema, G. 1991. A Highly thermostable neutral protease from Bacillus caldolyticus: cloning and expression of the gene in Bacillus subtilis and characterization of the gene Product. J. of Bact. 4107-4115.

Choi, I.G., Bang, W.G., Kim, S.H., and Yu, Y.G. 1999. Extremely thermostable serine-type protease from Aquifex pyrophilus. Molecular cloning, expression and characterization. 274: 881-888.

Chu, W.H. 2007. Optimization of extracellular alkaline protease production from species of Bacillus. J. Ind. Microbial Biotechnol. 34: 241-245.

Covan, D., Daniel, R., and Morgan, H. 1985. Thermophilic proteases: properties and applications. Trends Biotechnol. 3: 68-72.

Covan, D.A. 1997. Thermophilic proteins: stability and function in aqueous and organic solvents. Comp.
Biochem. Physiol., Part A: Mol. Integr. Physiol. 118: 429-438.

Felsenstein, J. 1985. Confidence limits on phylogenies: an approach using the bootstrap. Evolution. 39: 783791.

Gupta, A. and Khare, S.K. 2006. A protease stable in organic solvents from solvent tolerant strain Pseudomonas aeruginosa. Biores. Technol. 97: 1788-1793.

Hadaar, A. 2009. Two detergent stable serine-protease from Bacillus mojavensis A21: purification, charactecrization, and potential application as a laundry detergent additive. Biores. Technol. 100: 3366-3373.

Higgins, D., Blastby, A., Fuchs, R., and Clustal, V. 1992. Improve software for multiple sequence analysis. Comput. Appl. Biosci. 8: 88-192.

Jabeen, F. and Qazi, J.I. 2011.Production and characterization detergent compatible thermostable alkaline protease from Bacillus cereus FJ10. J. of Sci. \& Indust. Res. 70: 1042-1048.

Kumar, D., Gajju, H., and Bhalla, T.C. 2002. Production of a thermostable protease by Bacillus sp. APR-4. Asian J. Microbiol. Biotechnol. Env. Sci. 4: 533-540.

Mário, L.T., Florencia, C., Juliana, S., and Adriano, B. 2009. Purification and characterization of a peptide from Bacillus licheniformis showing dual antimicrobial and emulsifying activities. Food Research International. 42(1): 63-68.

Ningthoujam, D.S. and Kshetri, P. 2010. A Thermostable Alkaline Protease from a moderately Haloalkalithermotolerant Bacillus Subtilis Strain SH1. Aust J. of Bas. \& App. Sci. 10: 5126-5134.

Pakpahan, S. 2009. Isolasi Bakteri dan Uji Aktivitas Protease Thermofilik dari Sumeber Air Panas Sipoholon, Tapanuli Utara, Sumatera Utara. Thesis. Sekolah Pascasarjana. Universitas Sumatera Utara.

Rao, M.B., Tanksale, A.M., Mohini, S.G., and Deshpande, V.V. 1998. Molecular and biotechnological aspects of microbial proteases. Microbiol. and Mol. Biol. Rev. 62: 597-602.

Razak, C., Samad, M., Basri, M., Yunus, W., Ampon, K., and Salleh, A. 1993. Thermostable extracellular protease by $B$. stearothermophilus. World J. Microbiol. Biotechnol. 10: 260-263.

Rohlf, F.J. 1993. NTSYS. PC. Numerical Taxonomy and Multivariated Analysis System, Version 1.8. Applied Biostatistics. New York. NY.

Saitou, N. and Nei, M. 1987 . The neighbor-joining method: a new method for reconstructing phylogenetic trees. Mol. Biol. Evol. 4: 406-425.

Salleh, A.B., Basri, M., and Razak, C. 1977. The effect of temperature on the protease from Bacillus stearothermophilus strain F1. Mal. J. Biochem. Mol. Biol. 2: 37-41.

Sellek, G.A. and Chaudhuri, J.B. 1998. Biocatalysis in organic media using enzymes from extremophiles. Enzymes Microb. Technol. 25: 471-482. 
Sokal, R.R. and Sneath, P.H.A. 1963. Principles of Numerical Taxonomy. Freeman. San Francisco. pp. 181-185.

Srinivasan, T.R., Soumen Das, Balakrishnan, V., Philip, R., and Kannan, N. 2009. Isolation and characterization of thermostbale protease producing bacteria from tannery industry effluent. Recent Research in Science and Technology. 1: 063-066.

Synowiecki, J. 2008. Thermostable enzymes in food processing, in Recent Research Developments in Food Biotechnology. Enzymes as Additives or Processing Aids, Research Signpost, Kerala.

Takami, H., Akiba, T., and Horikoshi, K. 1989. Production of extremely thermostable alkaline protease from Bacillus sp. No. AH-101. Applied Microbiology and Biotechnology. 30: 120-124.
Tambekar, D.H., Kalikar, M.V., Shinde, R.S., Vanjari, L.B., and Pawar, R.G. 2009. Isolation and characterization of multilple enzyme producer Bacillus species from saline belt of Purna river. J. Appl. Sci. Res. 5: 10641066.

Turk, B. 2006. Targeting proteases: successes, failures and future prospects. Nat. Rev. Drug Discov. 5: 785798.

Van der Peer, Y. and De Wachter, R. 1994. TREECON for Wondows: a software package for construction and drawing of evolutionary trees for Microsoft Windows Environment. Comput. Appl. Biosci. 10: 570-596.

Wilson, P. and Remigio, Z. 2012. Production and characterisation of protease enzyme produced by a novel moderate thermophilic bacterium (EP1001) isolated from an alkaline hot spring, Zimbabwe. Af. J. of Microb. Res. 27: 5542-5551. 